line to pursue now, but I hope that the other issues raised here will continue to receive attention. For the present, one must regretfully conclude that adequate training in community psychiatry has hardly begun.

\section{ACKNOWLEDGEMENTS}

My enquiries on this subject were answered with the utmost helpfulness by Drs David Fisher, Donald Dick, Peter Brook, Alexis Brook, Leonard Fagin, Douglas Brough, Christopher Fleming, Ross Mitchell, Julie Hollyman, Paul Williams, S. Kumar, and Robin Murray and Professors Sydney Brandon and John Wing.

\section{REFERENCES}

'Richmond Fellowship (1983) Mental Health and the Community London: Richmond Fellowship Press.
${ }^{2}$ Brook, C. P. B. (1974) The postgraduate education and training of consultant psychiatrists. British Journal of Psychiatry, 124, 109-24.

1__ (1981) Postgraduate psychiatric training. Medical Education, 15, 335-39.

${ }^{4}$ Royal College of Psychiatrists (1982) Should community psychiatrists be specialists? A report on specialist status from the Working Party of the Social and Community Psychiatry Section. Bulletin of the Royal College of Pșychiatrists, 6, 190-94.

'DALly, P. (1982) Community psychiatry (Correspondence). Bulletin of the Roval College of Psychiatrists, 6, 66.

'Jablensky, A. (1982) Chapter in Psychiatrists on Psychiatry (ed. M. Shepherd). Cambridge University Press.

(See also correspondence from Dr Seidel, pages 35-36.)

\title{
UK Workshop on Organization and Management of Psychiatric Services
}

\author{
A. V. P. Mackay, Physician Superintendent, Argyll; and Bute Hospital, Lochgilphead, Argyll and \\ Peter Kennedy, Consultant Psychiatrist, Bootham Park Hospital, York
}

Stimulated by the First International Conference on Organization and Management of Psychiatric Services in Montreal in Spring 1983, an idea arose which was translated into the first UK Workshop on Psychiatric Service Management held from 17 to 20 July 1984 in York. The theme was economics, addressed by a talented group of British health economists. The meeting was structured into a series of presentations followed by group discussion, culminating in group exercises involving informed criticism of selected research papers on economic appraisals of psychiatric services. Seminar topics included: What do we mean by efficiency in the delivery of psychiatric care? (Professor Alan Williams); What are the costs of delivering psychiatric care? (Ron Akehurst); Switching resources (Professor Alan Maynard); Measuring outcomes of health (Professor Alan Williams); Choosing options with a limited budget (Mike Drummond and Ron Akehurst). A special evening discussion was led by Tim Nodder (Deputy Secretary at the Department of Health and Social Security) who gave an eloquent account of Health Service Strategy vis- $\dot{a}$ vis mental health over a thirty-year historical perspective.

Eighteen delegates* attended the conference; consultant psychiatrists and community physicians from the four corners of the UK. Initial reaction was generally one of anomie in the face of novel concepts and alien terms-a striking, if predictable, demonstration of poverty of formal planning skills possessed by senior clinicians. But this was rapidly replaced by appreciation and admiration for our teachers who systematically and painlessly led the party through the jargon-ridden world of option appraisal, marginal analysis, cost-benefit analysis and efficiency. In everyday terms, it reduces to the skills of informed decision-making, skills which are becoming increasingly desirable for clinicians who wish to earn a position of participation in the shaping of the service in which they work. Economic appraisal ceased to be felt as some bête noire, some threat to humane priorities of patient welfare, being seen instead as a crucial ingredient in wise planning. An essential point which was embodied in the aims of the meeting is that ignorance breeds suspicion of the economic dimension in psychiatric service planning and, further, that absence of a basic level of such skills leaves the clinician pathetically vulnerable to manipulation by his administrative 'advisers'.

This brief conference gave cause for hope; your nonmedical colleagues who would baffle you or exclude you are probably only a seminar or two ahead. Even if clinicians fail to acquire sufficient facility with economic techniques to lead a planning group, they can, indeed should, acquire the minimum level necessary with which to perceive the difference between sense and nonsense in the information they are given.

\footnotetext{
*The names of participants are listed here so that any interested members may contact a local colleague for further details about the Workshops: David Bainton (Bristol and Weston Health Authority, Greyfriars, Bristol); Brian Barraclough (Royal South Hants Hospital, Southampton); Richard Cundall (St John's Hospital, Stone, Aylesbury); Robert Davidson (Gartloch Hospital, Glasgow); Hugh Freeman (Hope Hospital, Salford, Manchester): Iain Glen (Craig Dunain Hospital, Inverness); Madge Kaczmarczuk (Castleford and Mormanton Hospital, Castleford. W. Yorks.); Peter Kennedy (Bootham Park Hospital, York); John Loudon (Royal Edinburgh Hospital, Edinburgh); Angus Mackay (Argyll and Bute Hospital, Lochgilphead); Robin Philpott (Royal Liverpool Hospital, Liverpool); Edward Renvoize (Bootham Park Hospital, York); Anthony Rugg (Clifton Hospital, York); Oliver Russell (4I St Michael's Hill, Bristol); Alan Stephens (St George's Hospital, Morpeth); David Tait (Murray Royal Hospital, Perth); Hugh Warren (Naburn Hospital, York); Bill Wintersgill (York Health Authority, York).
} 